\title{
Ideational Taxonomic Relation of Surah Al-Baqarah in English Translation
}

\author{
Siti Isma Sari Lubis \\ English Applied Linguistics Study \\ Program \\ Universitas Negeri Medan \\ Isma_great26@yahoo.co.id
}

\author{
Sri Minda Murni \\ English Applied Linguistics Study \\ Program \\ Universitas Negeri Medan
}

\author{
Zainuddin \\ English Applied Linguistics Study \\ Program \\ Universitas Negeri Medan
}

\begin{abstract}
This study investigates the types of Taxonomic Relation of Surah Al-Baqarah in English Translation. The Objectives of this study are to investigate the types of taxonomic relation used in English Quran translation of Surah Al-Baqarah. It was presented in a qualitative data analysis. The source of data was taken from the English Quran translation by Yusuf Ali. The data of this study were the clauses in English Translation of Surah Al Baqarah from the section 1 verse 40-103 and section 2 verse 104-141. The data analysis found out that the types of taxonomic relation in English Quran Translation of Surah AlBaqarah. They are repetition, synonym, contrast: opposition (antonym and converse), contrast: series (scales), class: class member and co-class, part: whole part and co-part in surah alBaqarah. Whereas, the contrast: series (cycles) was not found in both section of surah Al-Baqarah. The most dominant type that has been found in this research was repetition type which the function from section 1 and section 2 was to give command, warning, and prohibition.
\end{abstract}

Keywords - Taxonomic Relation; Al- Baqarah; English Translation

\section{INTRODUCTION}

Analyse the chain of relations between elements of text to the next is very interested to do. We can see the relation between lexical to unfold the text. There are some researchers have conducted research to see the relationship of the lexical based on its lexical elements to unfold a text especially in Quran, whether in its origin language or in its translation.

One of the analysis of the lexical relation in the Quran was done by Ilyas (2014). He analysed the cohesive device in the short surah of the Quran. It is based on its reference, substitutions, ellipsis, conjunction and lexical cohesive device. The lexical cohesive device was taken from Halliday and Hasan (1976) that stated that "not only the words that are in some way or other related to it but also all other words in the preceding passage, but it is the occurrence of the item in the context of related lexical items that provide cohesion and gives to the passage the quality of text and that grammatical alone cannot form a text unless this is matched by cohesive patterning of a lexical kind" which is the main categories of lexical cohesive devices are synonym, repetition, antonym or opposition and hyponymy. There are ten Surahs that analysed by Ilyas, they are Al-Kawthar Al-Nasr, Al-Ikhlas, Quraish, AlMasad, Al-Feel, Al-Falaq, Al-Naas, Al-Kafirun, and Al-
Fatiha. He found that all the categorization of the cohesive device was found in the short surah of Quran. However, it is not all of the surah consist of all the types. Such as in Surah Al-Kawthar there is only opposition while the types such as repetition, synonym, and hyponymy cannot be found. It happen in verse 1 which is opposite in verse 3 with the lexical fount (of abundance) opposite with the lexical cut off. While in Surah An-Nas repetition, synonym, and hyponyms can be found.

Additionally the lexical relation was done by Omari (2014). However he limited it and focused only to one type of sense relation that is synonymy involving English and Arabic. His study aims at viewing synonymy in both English and Arabic with specific reference to the Holy Qur'an. He stated that Muslim interpreters pay this phenomenon a great deal of attention since the synonymous words have a tremendous impact on clarifying and explicating the Qur'an meaning. Opinions and stances regarding synonymy vary greatly among those scholars whose primary goal is to interpret the intended meaning of the Holy Qur'an verse. He found that the synonymous words such as 'broad highways', (Al-Anbiya, Verse 31) and 'black intense in hue', (Fater, Verse 27). Another way of achieving emphasis is through the use of two successive synonymous words separated by (and) as a connective such as 'Without fear of being overtaken (by Pharaoh) and without (any other) fear', (Taha, Verse 77) and 'Naught doth it permit to endure, and naught doth it leave alone!', (Al-Muddaththir, Verse 28).

From the previous studies above, we can see that analyse the relationship between lexical elements to unfold the text is impossible to be done in Qur'an. Therefore language device that was used in this research is taxonomic relation by Martin and Rose (2007). Taxonomic relation is the part of Ideation. While the ideation itself has function to construe the experience. It focuses on sequences of activities, people and things which is involve in a discourse. Besides, how they associated to the places, qualities, and on how these elements are build up are related to each other as a text unfolds. Taxonomic relation describes the chains of relations between lexical elements in a text. It also describe as the overall pictures of people and things that a text construe.

Taxonomic relation consist of repetition, synonyms, contrast, class and part. However, the types contrast in taxonomic relation is divided into two, they are oppositions 
and series. Then, opposition consists of antonyms and converses while series consists of scales and cycles. Besides, the class type divided into two, they are class member and coclass. The last type, part, also divided into two, they are whole part and co-part.

Therefore, this paper tried to analyse the popular English Quran translation by Abdullah Yusuf Ali. The English translation of this Quran has been spread out all over the world included indonesia. The style of the language that tends to be soften and avoid the word with sexual conotation such as in Surah Yusuf to said the women that purified spouses as companions pure (and holy). Therefore, this research related to Quran that had taken from this book by the title Holy Quran:Text, Translation and Commentary. This research had taken surah Al-Baqarah which means heifer. Surah AlBaqarah consist of 286 verses and it is revealed in Medina. It is the second surah on the Quran. This surah was named heifer because there is a story about slaughtering heifer that ordered by Allah to the Israel. It is also the longest surah in the Quran. Besides, this surah also contain about the Israelity which there are 101 verses that will be made as the data of this study. It is in verse 40 until 141 . This verse was divided into sections. The first section is the verse $40-103$ and the second section is the verse 104-141.

\section{Methodology}

This paper used descriptive qualitative design. It limited to describe the taxonomic relation by Martin and Rose (2007) in Surah Al-Baqarah which is means heifer in Quran English Translaion. Taxonomic relation itself consist of repetition, synonyms, contrast, class and part. All the taxonomic relation will be analyze in the verse 40 until verse 141 . They are namely section 1 (verse 40-103) section 2 verse 104-141) The data of the study is Surah Al-Baqarah which the clause has the features that related to taxonomic relation. It divided into repetition, synonymy, contrast, class and part. The source of the data is taken from surah Al-Baqarah in English Quran Translation by Yusuf Ali.

The data collected by using the documentary technique. The researcher read and selected the clause that has features of lexical that related to taxonomic relation. Then they were analyzed by using interactive models of Miles, Huberman and Saldana (2014). The data were analyzed into several phases, (data collection, data condensation, data display, and data verification/ conclusion)

\section{FINDNG AND DISCUSSION}

The types of taxonomic relation that can be found in surah Al Baqarah for section 1 and 2 are repetition, synonym, contrast, class and part. The most dominant type of taxonomic relation that can be found in Surah Al-Baqarah for section 1 and section 1 was repetition. In section 1 , there were 66 occurrences from the 96 sum of data. It is about $69 \%$ from the whole. While in the section 2 , there were 41 occurrences from the 61 sum of data. It is about $67 \%$ from whole. It is in line with the theory of Martin and Rose(2007) who stated that the function of repetition is to enable the readers or listener to keep one or more lexical strings relatively simple while complex lexical relation are constructed around them. It can be seen such as in the lexical the children of Israel. This lexical was repeated three times in the section 1. It happened in the first clause which is functioned to show that the next clause is pointed to the children of Israel. The second occurrences was in the clause 28 , it is enable the reader to keep the lexical was tracked to the next and previous clauses to show the discussion about the clause one until 28 is related and purposed to the same people. However, for the last occurrences, in the clause 183, this lexical was functioned not only to keep the text tracked as the second occurrences done, it also functioned as the warning to the children of Israel. Therefore another function of repetition from Martin and Rose (2007) was found. There are many lexical that were repeated not only to enable the reader keep the lexical string simple but also to warn, to command, and to prohibit the children of Israel, believe people and also the reader as has been presented in the data analysis.

In line with Huneety, et al (2017) who found that repetition is the most dominant type when they conduct a research that contrasted the lexical cohesion both Arabic and English in Religious discourse. From the 1227 occurrences in Arabic, there were 340 repetitions while in English there were 221 repetition from 864 occurrences. He also said that repetition creates a lexical tie between many items that belong to the same root and thus helps keep the text unified. It is same with the function of repetition that has proposed by Martin and Rose (2007) in this research. Besides, related to the additional function, it is also in line with Huneety, et al (2017), who said that repetition is widely used as a rhetorical device that plays a major role in creating emphasis on certain points, attitudes or views. In Huneety's research repetition was used on certain point that related to have powerful emotional effect when the religious discourse was presented. While in this research, repetition used to emphasize command, warning, and prohibition that related to the grace, rewards, and punishment that would be gotten by the Israel and believe people if they do bad and good deed as what had been ordered by Allah.

Therefore, it is in line with Fadhilah (2018) she also found the same function with this research. She analyzed the English Quran translation in surah Al-Muzammil that translated by Arberry and Ali. In verse 20, Arberry's translation is "therefore, recite of the Koran so much as is feasible, so recite of it so much as is feasible" while from Ali is " read ye, therefore, of the Quran as much as may be easy for you.. read ye, therefore as much of the Quran as may be easy (for you). The meaning of sentence both Arberry and Ali is similar although they used the different lexical that was repeated. It showed that the repetition of the lexical feasible in Arberry's translation and lexical easy in Ali's translation has the same function. Both of these lexical used as the command to the reader of the Quran to read which easy or able to read.

Since repetition is often found in Quran translation, Ali (2016) presented the repetition as the translation form or meaning in the Quran. He said repetition is an important characteristics of Arabic text. Therefore it was a truism that 
repetition is the lexical rhetorical device that can be found in Quran. It plays a vital role that functioned to keep the translation of the Quran accurately from the original one. Besides, translator has an attempt to maintain the accuracy and faithfulness, and at the same time maintain the flow of the translation, make use of footnotes to draw the attention of the reader/critic to the actual wording of the original. In this way, the translator minimizes the effect of mistranslation from the form of the original on the translation. Therefore he argued that each repeated word in the Qur'an text serves a particular purpose which may be totally defeated, and, perhaps, the whole message distorted if the translator fails to render repetition in the same way.

Similar with what had been proposed by Martin and Rose (2007). In the other discourse, repetition also can be found as the dominant type. Pratiwi, et al (2016) analyze the lexical cohesion in the editor's note of Indonesia tatler traveler magazine. They said that repetition is often occur in the written text such as magazine. They found that repetition occur 14 times in the editor's note of Indonesian tattler traveler magazine. Repetition of word that repeated in the magazine text is commonly functioned as reference.

In contrast with Astuti (2017) that found repetition was also the most dominant type in written text although it is in a short text such as short story The Tell-Tale Heart by Edgar Allan Poe. She analyzed the lexical cohesion in this short story that divided it into three kind of word class. They are repetition of Pronoun, repetition of Noun and repetition of Verb. Her findings is slightly different with this study that related to the choice of the class word that used and taken in the repetition. In this study, all the kind of taxonomic relation was taken from the noun, adjective, and adverb. The repetition of verb was not taken because taxonomic relation build up a picture of people, things, places and qualities. While the repetition of pronoun was not taken to avoid the misunderstanding related to the usage of pronoun in Quran such as the subject Allah that sometimes used the pronoun "I" and sometimes used the pronoun "We", while when certain discussion also pointed to the other subject that also use the pronoun We that tracked to the Israel and belief people. From the 137 repetition that had found by her, there are 32 repetition of nouns. While the function of repetition is similar with this research is to stresses the main point. However, because she analyzed the short text that related to fiction text, the repetition that used has different function. It used to convey the message in much more engaging and notable way besides it also enhances the beauty of the sentence.

In contrast with the research that had conducted by Latupeirissa et al (2018), they found the different function in Indonesian political language. It was taken from the political language that delivered by Soekarno. They found that the main character of Soekarno's political language is repetition and examined why the repetition was applied in in soekarno political speech. They found that there are 206 repetition that can be found in Soekarno's political speech. The first function was similar to astuti (2017), it was used as the rhetorical device while the second function is repetition was used as the vehicle device of Ideologies. They believe that the main ideas of each segment that delivered in Soekarno's political speech as the main ideology toward several ideology that has relation to unity, revolution, imperialism. However, as political discourse has function to persuade the listener or reader, the function of repetition that related to the ideology is also related to ask the listener or reader to take their position related to the ideology that has delivered. In the other hand, while several repetition was delivered in the Quran it is not functioned to pursue but to command the reader by presenting it clearly such as in the repetition in section 1 , it is related to the repetition of the lexical truth in verse 42, "and cover not truth with falsehood, nor conceal the truth" it related to command the reader without making the reader to take the position whether they will do it or not as the political speech had done that the reader or listener can take their position. Command as the function of the repetition in the Quran make the reader do something and if they don't do it, especially for the followers they will consider rejecting and don't obey what Allah had command to them. It is similar with the function as warning and prohibition.

The other 4 types of taxonomic relation showed no significant difference. In the type synonym type of taxonomic relation, which the Martin and Rose (2007) said that synonym is different lexical item that share similar experiential meaning. The function is similar with the repetition, however they have significant differences, because the translator tried to maintain the accuracy and faithfulness of the meaning with the source language as stated by Ali (2016) which the language that used in Al-Quran is different with the language that used in Arabian social life as the native speaker of Arabic.

Additionally, related to the function of synonym, it is different with the research that had been conducted by AlGhazălli (2015). He analyzed the translation assessment of Qur'anic lexical synonyms that can be found in many Qur'an Verses from Six published translations. Al-Ghazălli (2015) then determined which lexical is most appropriate to the lexical authentic meaning of Quran. He said that the function of synonym enable language users to avoid repetition and express emphaticness or hyperbole in a more rhetorical style by employing homonyms, rhythm etc. While in this research the synonym used to enable us to keep one or more lexical strings relatively simples or as the resources in the complex field of the text and showed the significant differences with the total of repetition (66:7). Therefore, why synonym and repetition has significant differences in this study, it probably because the repetition was used to avoid the misunderstanding in the text rather than use the different lexical word although convey the similar meaning.

Related to the type contrast which the elements that differ significantly in meaning (Martin and Rose, 2007), the researcher found the pattern of contrast type in section 1 and section 2. There were 9 type of contrast. It also has significance different in the total with repetition (66:9). According to Al-Kharabsheh and Ghaith Al-Jdayeh (2017) 
that conducted a research related to the contrast meaning in Quran, they found that Ali's translation style was indirect and philosophical, rather than precise and to the point therefore, when translated the Quran in contrast type it more semantically metaphorical rather than filled the gap antonym of words. It can be one of the reason why the contrast type has different total with repetition

Related to the function of contrast, it is important resource for contrasting arguments and interpretation, in which a set of behavior or qualities is preferred over another. In section 1, the lexical right is contrast with the lexical wrong, it was use an antonym to emphasize two things that related to the behavior that in one side (right criterion) need to be prefer to another side (wrong criterion) through the scripture that given to Moses Moses. Additionally, contrast also functioned to associated things that compared because of social roles. Such the lexical men that converse with wife. In this case both men and wife plays the roles of two people as the couple that testified to be discord. This similar function was also found by Al-Kharabsheh and Ghaith Al-Jdayeh (2017). There are ten lexical that analyzed and considered to be contrasted by them, however, if it categorize to taxonomic relation, it would found the types contrast:opposite which belongs to the antonym and converse. They are: blind converse with sight, darkness antonym with light, the companions on the right hand side converse with the companions with the left side, white antonym with black, the minor torment converse with the greater torment, those come early to the prayer antonym with those who come late to the prayer, palatable, sweet, and pleasant to drink' antonym with 'the other, salt, and bitter', bad antonym with good, guidance antonym with misguidance, and the living antonym with the dead. From the ten lexical that had been chosen by them and consider as the lexical that has contrast in meaning, there was no one lexical that can be categorized as the scales or cycle of contrast type. It happen because, no one lexical that has the pattern as the scales and cycle. Therefore, we can conclude that analyzed lexical in text will be more detail by using taxonomic relation.

The other function of the contrast that also can be found in this research is interpreting things and events. It constructed classifying in which one class of phenomenon is distinguish from another. It is found only one in the lexical heifer. It is interpret the things that need to be chosen when Allah ordered to sacrifice the heifer (that in the previous they worship heifer), and was asked by the Moses' people or his followers about the kind of the heifer that will be sacrified. Then Moses gave the detail of heifer that need to be sacrifice by contrasted it in scales of age, that the heifer is not too old nor too young but in the middle age. Therefore, through the function of taxonomic relation above we can see that the branch type of taxonomic relation can be found. They are antonym, converse, and scales.

The researcher cannot find one of the branch type contrast: series: cycles in section 1 and 2. Additionally, in the section 2 the types contrast: series: scales also cannot be found. It means that the result of this study is slightly different from the theory by Martin and Rose (2007) who divided the element of contrast into four elements. While in this study, we only could find 3 element in section 1 and two elements in section 2 which the types of contrast:series:cycle could not be found in both section. It happens because in section 1 and section 2 there was no thing that contrasted related to the day, week, or year. As the branch type contrast: series: cycles means the ordering items between two others, such as days of the weeks or years. In contrast type, Section 1 and 2 dominantly contrasted thing that related to social roles. It happened because section 1 and 2 discussed about the good and bad thing that need to do which is related to the deed of Israel and Muslim as had presented above. The different between section 1 and section 2 was found in the branch type contrast: series: scales. Martin and Rose (2007) said that scales have outermost poles of meaning.

Related to the similar research about the taxonomic relation that had done by Grahmayanutri (2017) in different case that related to the oral tradition wedding that has pronounced and then transcript into text. There are three categorize of people's utterance that she had transcribed and then analyze based on the pattern of taxonomic relation. The result was different with this research although even analyzed with the same language device. The types of taxonomic relation that can be found only type repetition, synonym, class and part. The contrast type can not be found in her research, even, it its branch types. Additionally, the similar research was conducted by Nasution (2017). It is also in oral tradition wedding and transcribed into text. In Nasution's research, she found that the contrast types could be found in three text that she had analyzed related to taxonomic relation. However, she only found the types contrast: opposite: antonym and converse. There was no type of contrast:series whether in scales and cycle. Additionally, Khoir (2017), that also conducted a research that delivered orally then transcribed into text. He analyzed the taxonomic relation in stand up comedy which had been planned before and also could not find the types of contrast even, all the types of taxonomic relation.

It can be concluded that, this is one of the phenomenon that need to be researched further related to taxonomic relation in oral and written text. Whether if it is in oral, the taxonomic relation of contrast type will be less to be found than in writing.

The other types of taxonomic relation that can be found is class. It was divided into two. They are class member and coclass. Class member can be found in the section 1 and section 2 , while the co-class only can be found in section 1 . There are two function of the class that can be found in this research, the first is to classified several element in each clause as strings of lexical relation as the events unfold. In the verse 62 we can see clearly the several people that classified will have reward from Allah. The member of who believe in the Quran, follow the Jewish (scripture), the Christians, the Sabians, who believe Allah and last day, and who working rightenousness was constructed to unfold the picture of the class people that considered will have the reward from Allah. It is in line with the theory by Martin and Rose (2007) who said that several elements in the text construct an unfolding picture as member 
whether it is more general that related to whole class or more specific that refer to the relation between one instances of a class that related to co-class. The second function was to restriction definition of selected lexical in a text. Such as the lexical apes, the lexical item apes was included into the type of co-class. It is because apes unilaterally entails with monkey. Monkey is a superordinate of apes.

Related to the last type Part that similar to class. It represents the part of the word. Related to Martin and Rose (2007), class and part are the foreground the ideational function of lexical relation in building a filed. It unfold the text that can made as the system in unfolding the picture of elements in the clause as the class or part.

Additionally, all the type of taxonomic relation has the different result with research that conducted by Ilyas (2014). $\mathrm{He}$ analysed ten short Suras in Quran based on cohesive device which concern with the text relation that beyond the boundary of sentence. From the ten suras that he had analysed, he found that repetition almost occur in every sura except, in surah An-Nasr and Al-kawthar. While the type antonym only can found in three surahs, they are al-kawthar, al-Falaq, and Al-fatihah. Besides, the type hyphonym which is similar to the class. It is only in surah Al-Nas with the lexical Jinn and Mankind in verse 6 that are relation hyponyms in relation to verse 5. Compared to this study, hyponym that called as class in taxonomic relation also can be found. It divided into two class member and co-class. Both of this type can be found in section 1 and section 2 . There are 7 occurrences in section 1 which is 5 in class member and 2 in co-class. While in section 2 which the text is shorter than section 1, there are only 5 occurrences that only can be found in class member type. Therefore, it can be concluded that different text will use different dominant type of taxonomic relation. Besides, the length of the text in Quran will make us more possible to find the more type of taxonomic relation in the Quran. Such as in this research which is the length of section 1 is longer than section 2 found more type and occurrences of taxonomic relation, then compared to the research that had done by Ilyas(2014) that discussed only short verse or text in the Quran.

\section{ACKNOWLEDGMENT}

Big thanks to my adviser Mrs. Minda and Mr. Zay who has inspired me to do this research. thank you for all your suggestion commend so that I can finish this research.

\section{REFERENCES}

[1] Ahmed Abdel-Fattah M. Ali. (2006). Word Repetition in the Qur'an Translating Form or Meaning?. J.King Saud Univ., Vol. 19, Lang. \& Transl., pp. 17-34, Riyadh

[2] Aladdin Al-Kharabsheh and Ghaith Al-Jdayeh. (2017). Translatability of Qur'anic Antonymy. Jordan Journal of Modern Languages and Literature Vol.9, No. 1, 2017, pp 51-72

[3] Al-Omari, Sana Kamel \& Abdel-Rahman Husni Abu-Melhi. (2014) Synonymy in English and Arabic with Reference to The Holy Qur'an: A
Contrastive Study. Theory and Practice in Language Studies, Vol. 4, No. 12, pp. 2619-2626,

[4] Anas Huneety, Bassil Mashaqba, Sabri. Shehadeh .Y. Al-Shboul Abdallah Tayseer Alshdaifat. (2017). A Contrastive Study of Cohesion in Arabic and English Religious Discourse. International Journal of Applied Linguistics \& English Literature ISSN 2200-3592 (Print), ISSN 2200-3452 (Online) Vol. 6 No. 3 Australian International Academic Centre, Australia

[5] Ayu mamriatul fadlilah. 2018. A study on lexical meaning of the English translation in surah al muzammil. Thesis

[6] David Samuel Latupeirissa, I Ketut Darma Laksana, Ketut Artawa, I Gusti Ayu Gde Sosiowati. 2018. Repetition in Indonesian Political Language. International Journal of Linguistics, Literature and Culture Vol. 4, No. 6, November 2018, pages: 72 80 ISSN: 2455-8028

[7] Ilyas, Asim Ismail. (2014) Cohesive Devices in The Short Suras of the Glorious Quran. Arab Open University, Jordan Arab World English Journal. ISSN: 2229-9327

[8] Martin, J. R. (1992). English Text: System and Structure. Philadelphia: John Benjamins.

[9] Martin, J. R., \& Rose, D. (2007). Working with Discourse (2nd ed.). New York, NY: Continuum.

[10] Mehdi Fălih al-Ghazălli, 'Alăa Jabr al-Musawi. (2015). Translation Assessment Of Qurănic Lexical Synonymy Into English. International Journal of English Langue and Linguistics Research Vol.3, No.2, pp.2845 ,.

[11] Miles and Huberman. (1994). Qualitative Data Analisys: An Expanded Sourcebook. Edition 2, London: Sage

[12] Miles, B., Matthew, A. Huberman, Michael and Saldana. (2014). Qualitative Data Analysis: A Methods Source book. Edition 3. USA: SAGE

[13] Ni Putu Tika Asri Astuti.K1*, Ni Made Suwari Antari2, I Wayan Mulyawan. 2017. Lexical Cohesion Found in Story The Tell-Tale Heart by Edgar Allan Poe. ISSN: 2302-920X Jurnal Humanis, Fakultas Ilmu Budaya Unud Vol 18.2 Pebruari 2017: 176-183

[14] Sang Ayu Dwi Janu Pratiwi1, I Made Rajeg, Ni Ketut Sri Rahayuni. 2016. Lexical Cohesion Found In The Editor's Note Of Indonesia Tatler Traveller Magazine ISSN: 2302-920X Jurnal Humanis, Fakultas Ilmu Budaya Unud Vol 16.1 Juli 2016: 269 - 275

[15] Yusuf, Ali. (1938). Holy Quran:Text, Translation and Commentary. New York. 